\title{
Prevalent Factors that Affect the Job Satisfaction of Junior High School Technology and Livelihood Education Teachers in Public Secondary Schxcool in District 1 of Marikina City $2017-2018$
}

\author{
Jackie D. Urrutia, Renee Roseller V. Grafilon, Edward Patrick L. Mortera, and John Cristian A. \\ Ramos
}

\begin{abstract}
The objective of this study is to examine the prevalent factors that affect the job satisfaction of Technology and Livelihood Education Junior High School teachers in Public Secondary School in District 1 of Marikina City. Also, this research helps the educational stakeholders to empower teachers' capacity through assessing their satisfaction from their jobs. Out of 110 respondents, researchers gathered only 86 samples according to the COCHRAN as sample technique used. Questionnaire has been adapted so reliability testing and validation was not utilized. Descriptive Statistics showed that teachers are agreed in four aspects. However, teachers' responses in Job Characteristics aspect have at least satisfied. Moreover, independent t-test and ANOVA are being utilized by the researchers to reveal the significant differences of teachers' job satisfaction in relation of gender, age and type of schools, but there were no significant differences at all. Furthermore, bivariate correlation (Pearson - $r$ ) is being used by the researchers to determine the significant relationship to each aspect. Based on the findings, there were significant relationships in each aspect. Lastly, regression method was being used to examine what aspect of Job Satisfaction is the predictor of teachers' intention to remain on the job. Researchers found out that Meaningfulness of the Job and Social Benefits are the predictors of the teachers' intention to remain on the job. With these findings, the researches recommend to include other educational stakeholders to have a comparison in terms of Job Satisfaction; Administration have a clear content and natures of the assigned task to their teachers because this is one of the factor why teachers do not remain in the job; Administration must to pay attention to support their teachers; and there are other aspects, factors, and theories that can be used to fully identify the level of satisfaction of teacher, so further research is needed to be studied.
\end{abstract}

Keywords: Intention, Job Satisfaction, Motivation, Multiple Linear Regression, Marikina City.

\section{INTRODUCTION}

Teachers' satisfaction is very valuable thing to consider for

Revised Version Manuscript Received on 10 September, 2019.

Jackie D. Urrutia, Professor, College of Education-Graduate School, Polytechnic University of the Philippines, Sta. Mesa, Manila, Philippines. (Email: jackieurrutia20@gmail.com, jdurrutia@pup.edu.ph )

Renee Roseller V. Grafilon, Teacher 1, Sta. Elena High School, Marikina City, Philippines. (Email: reneerosellergrafilon@ gmail.com)

John Cristian A. Ramos, SHS Faculty, University of the East Caloocan, Caloocan, Philippines. (Email: itianramos@gmail.com)

Edward Patrick L. Mortera, Teacher 1, Don Ramon E. Costales Memorial National High School, Pangasinan, Philippines. (Email mortera744@gmail.com) them to work faster, effective and reinforce good stimulus due to high demand of the assigned duties and responsibilities given by their heads. School policies, supervision, interpersonal relations, opportunities for promotion and growth, working conditions, work itself, achievement, recognition and responsibility are facets that teachers somehow satisfied with [1]. One way to assess if teacher is happy and contented to his work and to its environment is through job satisfaction measurement. It must be matched on what they have to receive from their work to motivate them to be effective and efficient individuals. It must be matched on what they have to receive from their work to motivate them and how the administration empowers them to be effective and efficient individuals [2]. However, the assumption that they believe continuously is that if a teacher rendered a lot of years in school, they are more compensated, happy and satisfied to their job [3]. An employee is an important resource that the company has that can affect the operation of the system. Teachers' evaluation performance is the objective way to boost confidence and uplift morale. It could explain by giving rewards and incentives. This is also the intervention that the administrators and subordinates to correct the deficiencies of the existing to the system to function well.

\section{RESEARCH PARADIGM}

The researchers used the Predictors of Teachers' Intention to Remain in the Job as conceptual framework. It asserted job characteristics and support from administration influence the level of job satisfaction to teacher. Moreover, it suggests that meaningfulness of the job and social benefits contribute to both level of how satisfied teachers' in their job and their intention to remain in the job. Then, factors that can contribute to teachers' level of satisfaction are same factor that contribute to teachers' intention to remain in the job. 
PREVALENT FACTORS THAT AFFECT THE JOB SATISFACTION OF JUNIOR HIGH SCHOOL TECHNOLOGY AND LIVELIHOOD EDUCATION TEACHERS IN PUBLIC SECONDARY SCHXCOOL IN DISTRICT 1 OF MARIKINA CITY 2017 - 2018

\begin{tabular}{|l|l|l|}
\hline $\begin{array}{c}\text { Independent } \\
\text { Variables } \\
\text { Job Satisfaction } \\
\text { Aspects } \\
\text { - Job } \\
\text { Characteristics } \\
\text { - Meaningfulness } \\
\text { of the Job } \\
\text { - Social Benefits } \\
\text { - Support from } \\
\text { Administration }\end{array}$ & $\begin{array}{c}\text { Dependent } \\
\text { Variables } \\
\text { Job Satisfaction } \\
\text { Aspects } \\
\text { - Intention to } \\
\text { Remain on the } \\
\text { Job }\end{array}$ \\
\hline
\end{tabular}

Figure 1: Research Paradigm of Job Satisfaction

\section{A. Objectives of the Study}

The general objective of this study was to identify what are the aspects of Job Satisfaction teachers are satisfied with. It is also want to: (1) determine the demographic profile of Public Secondary Technology and Livelihood Education in Marikina City in terms of Gender, Age, Marital Status, Teaching Experience, Type of School, Location of the School, Grade Levels, Leadership Position and Educational Attainment; (2) find out their responses in the following aspects in terms of Job Characteristics, Social Benefits, Meaningfulness of the Job, Support from Administrators and Intention to Remain on the Job; (3) find out if there is any significant difference between job satisfaction aspects and gender, age, and type of school; (4) find out if there is any significant relationship among job satisfaction aspects; and (5) determine the factors contribute to teachers' intention to remain on the job.

\section{B. Scope and Limitation}

This study considered the job satisfaction of TLE teachers in District 1 of Marikina. The study will further obtain information regarding the job satisfaction. Since the study is a descriptive-survey research, it is limited and will be conducted at Marikina, District 1. A researchers' questionnaire will be administered to the selected respondents which are the Technology and Livelihood Education Teachers in District 1 of Marikina through random sampling. The data gathered should be treated to determine the factors of job satisfaction. The questionnaire used by this study was being adapted [4].

\section{REVIEW OF RELATED LITERATURE}

Job satisfaction and motivation concepts are often misunderstood as being synonymous to each other. The fact is that these concepts are much related to each other, that is, they are like two sides of the same coin. [5].

There have been different studies conducted on the phenomenon of job satisfaction on various countries that reveal different factors. "First, the job environment itself and factors that are associated with job are important influences of job satisfaction. This includes how people are treated, the nature of job tasks, relations with other people in the work place, and rewards. Second, there are individual factors that the person brings to the job [6]."

Ganiron [7] stated that it makes a significant contribution to the observing link between job satisfaction and organizational performance in both directions, whereby it is particularly important to emphasize the contribution of observing the link between organizational performance and job satisfaction. Tabuso [8] believed that teachers who are committed are those who devote themselves wholly to the teaching profession and to the vocational organization.

An article written by Gamboa [9] during the celebration of the World's Teacher's Day, he cited that:

"...we have to remind ourselves that our teachers - Filipino teachers to be precise - need the proper environment to fulfill the immense role that society expects from them. Perhaps the biggest challenge facing our teachers, especially those serving in public schools, is the salary. We frown on the stories of teachers that coerce their students or the student's parent to buy goods from them. And while this is clearly an ethical breach, we have to understand why this is happening."

The DepEd Secretary Briones [10] made the statement in 2016 at the awarding of certificates to Metrobank Foundation's most outstanding teachers, she said:

"There's a teacher everywhere. Whether in times of war, times of peace, times of prosperity, in places of joy, there is always a teacher and we will recognize each and every one of them,"

As stated by Bolin [11] in his study revealed that Personal background or demographic factors are the factors which refer to such aspects as: an individual's gender, age, educational background, teaching subjects and job experience among others. As stated by Mason [12], "the question whether or not gender differences in job satisfaction exist has been answered both affirmatively and negatively in the literature."

According to the research conducted among Canadian teachers by Ma \& MacMillan [13], it was revealed that job satisfaction levels differ significantly between male and female teachers.

Similarly, the results of research that was conducted in the United States revealed that there were significant differences in the levels of job satisfaction between male and female teachers (Bishay, [14]. They say that female teachers were more satisfied with their job than male teachers. Whereas, Zhongshan [15] found that elementary school male teachers in Shanghai, China were more satisfied with their salaries than their female colleagues. Conversely, Crossman and Harris [16] conducted a study on job satisfaction among secondary school teachers in United Kingdom and their findings indicated that their satisfaction levels did not differ significantly by gender.

According to Rasku and Kinnunen [17], findings of a study conducted among teachers in Finland revealed that there was a strong relationship between the teacher's age and job satisfaction. They found that teachers' job satisfaction was linked to their age. On the other hand, Crossman and Harris [16] found that secondary schools teachers in United Kingdom did not differ significantly in their job satisfaction in relation to age.

Furthermore, Zhongshan [15] found that work satisfaction among Chinese teachers increases with the increase in age. Greenberg \& Baron [18], supported the idea that the higher 
the teacher's age, the higher the level of job satisfaction and the lower the teacher's age, the lower the job satisfaction level. Thus, earlier studies indicate that there is a significant difference in job satisfaction caused by age differences. Also, Bennell and Akyeampong [19] conducted a survey on teacher motivation found that young Tanzanian teachers were less satisfied with their job than their older counterparts who felt being teachers by profession was a privilege. Therefore, teachers differed significantly in job satisfaction with regard to age.

It was conducted among primary and secondary school teachers in Greece revealed that there were no significant differences in levels of teachers' job satisfaction with regard to marital status according to Koustelios. This means that secondary school teachers in Greece did not differ in their job satisfaction levels in relation to marital status.

On top of that, teaching experience refers to the number of years a person has served as a teacher. Crossman and Harris [16] call this the "length of service". According to Koustelios, the teachers with long teaching experience indicated higher levels of job satisfaction with such aspects as pay and supervision. In other words, the level of satisfaction increased with the increase in years of service in the teaching profession (ibid).

Also, Greenberg and Baron [18] contend that employees with many years of service perceived higher job satisfaction than their colleagues with 39 less job experiences. Ironically, Crossman and Harris [16] found that teaching experience or length of service did not contribute to any significant differences in job satisfaction among secondary school teachers in the United Kingdom.

Empirical research data of a study that was conducted in the United Kingdom indicated that teachers differed in job satisfaction in relation to the type of school in which they worked [16].

The teachers who worked in independent and private schools in the United Kingdom indicated higher levels of job satisfaction than their colleagues in other types of schools. However, other research findings indicate that teachers in public and private schools did not differ in the job satisfaction levels significantly 15$]$.

According to Crossman and Harris [16] Empirical research data of a study that was conducted in the United Kingdom indicated that teachers differed in job satisfaction in relation to the type of school in which they worked. Although, other research findings indicate that teachers in public and private schools did not differ in the job satisfaction levels significantly [15].

Furthermore, earlier study findings indicated that teachers who worked in schools that are in the remote/rural areas were less satisfied with their jobs than those working in urban areas [19]. This implies that the location of school was a determinant factor of their differences in job satisfaction.

Since educational attainment is one of the significant factors that influence faculty performance, pursuing post graduate studies, trainings and fellowship in duly accredited colleges and universities by faculty and personnel may be rewarded as a matter of policy considering that completion of the degree affects their job satisfaction and performance. Further, scholarship must be granted to obtain the necessary qualifications. [20]
Earlier study findings indicated that teachers who worked in schools that are in the remote/rural areas were less satisfied with their jobs than those working in urban areas according to Bennell \& Akyeampong [19]. Lastly, according to Greenberg and Baron [18], employees occupying managerial or leadership positions in the organization indicate higher levels of job satisfaction than others. This implies that teachers who occupied senior positions like being Deputy Principal, Senior Academic master/mistress, and Head of Department among others in their respective schools were more satisfied with their job than their colleagues without such promotional positions. Likewise, other studies found that teachers who had earned promotions in their schools were more satisfied with their job than others.

Job satisfaction is a multidimensional phenomenon and it is therefore argued that different scholars identify different job satisfaction factors or facets [11]. Moreover, Davidson [21] conducted a survey on teacher motivation in Tanzania and he found that most teachers were unhappy with their pay, fringe benefits, teachers ${ }^{\text {ee }}$ accommodation, their promotion position, status and number of lessons allocated.

This implies that they had a low level of job satisfaction. The current study is intended to examine what other factors behind teachers ${ }^{e e}$ job satisfaction there are besides teacher motivation, which the above researcher studied.

According to Woods and Weasmer [22], workerse job satisfaction is derived from collegial relationship that they enjoy at their place of work. It is very important for teachers to have time to share experiences (ibid). Ellis, quoted in Latham, [23], argues that teachers ${ }^{\text {ee }}$ motivation and job satisfaction are associated with "intrinsic and extrinsic rewards". Intrinsic rewards include such issues as: professional development, nature of work itself and sense of achievement, while the extrinsic ones include pay and job security [23]. This implies that in studying employees ${ }^{\text {ee }}$ job satisfaction one has to incorporate these aspects.

Majority of the teachers are somewhat satisfied on the following facets: school policies, supervision, interpersonal relations, opportunities for promotion and growth, working conditions, work itself, achievement, recognition, and responsibility [24]

In job satisfaction of the teachers, the teachers are satisfied in terms of the hygiene factors of their job. Specifically, majority of the teachers are very much satisfied with their job status, interpersonal relationship and physical condition of the school and supervision. Many teachers have also considered their salary to be satisfying (Pilarta, 2015)

This study resorts to the Spector's [6] definition of the concept of job characteristics. According to him the term job characteristics refers to "the content and nature of the tasks themselves". Job characteristics include such elements as: "(1) skill variety, (2) task variety, (3) task significance, (4) autonomy and (5) job feedback" (ibid).

Job characteristic theory [26] proposed a framework to study how particular job characteristics affect job outcomes and job satisfaction. The framework states that there are a number of core job characteristics that impact on job 


\section{PREVALENT FACTORS THAT AFFECT THE JOB SATISFACTION OF JUNIOR HIGH SCHOOL TECHNOLOGY AND LIVELIHOOD EDUCATION TEACHERS IN PUBLIC SECONDARY SCHXCOOL IN DISTRICT 1 OF MARIKINA CITY 2017 - 2018}

outcomes. These are: Skill Variety (the degree to which a job requires a variety of different activities in carrying out the work and involves the use of different skills and talents of the individual), Task Identity (the degree to which the job requires completion of a 'whole' and identifiable piece of work - that is, one that involves doing a job from beginning to end with a visible outcome), Task Significance (the degree to which the job has substantial impact on the lives or work of people in other departments in the organization or in the external environment), Job Autonomy (the degree to which the job gives the employee substantial freedom, independence, and discretion in scheduling the work and in determining the procedures to be used in carrying it out) and Job Feedback (the degree to which carrying out the work activities required by the job results in the individual obtaining direct and clear information on the results of his performance).

The concept is defined as "the extent that an individual perceives their work as significant and important and the degree to which an individual perceives their job as affecting other people "s lives" [27].

Michaelowa [28] concluded, that if the intention of school administrators is to improve both teachers' career satisfaction and students' achievement, teachers educational level should not be raised beyond the Baccalaureate degree. This suggests that teachers with high educational attainment should be discouraged at the primary and secondary levels of education.

During the Educator's Congress in 2000, former DepEd Secretary, Bro. Andrew Gonzales[29] said:

"Studies conclude that the quality of the principal is as important as the financial and physical/material considerations in school improvement efforts. Expanded decision-making, authority of school heads, availability of instructional outputs, competence and professional commitment will make a difference in creating effective school. Likewise, the quality of decisions made by an empowered principal will give a heavy impact on the quality of learning taking place in the classroom.. Through the dynamic leadership and efficient management style of an empowered principal, quality education can be immensely improved."

Getzels and Guba [30] cited that Educational administrators must learn to exert himself energetically' strive for achievement and higher status; relate successfully to other people; view the future with confidence, the present with understanding, the past with satisfaction and adjust well to frustrating irritations and criticism in pressure situation.

According to Fatima [31] The teachers who receive helpful suggestion which was found to be $79.4 \%$ and guidance from their supervisor then they will be more satisfied from their job.

According to Latham [23], "job satisfaction can do far more than help retain teachers; it can improve their teaching." This implies that satisfied teachers can contribute significantly to the improvement students $^{\text {ee }}$ academic performance and school effectiveness at large.

According to the research of Romero and Bantigue [32], the results show that Kto12 teacher- respondents will show job satisfaction if he is assured of a promotion /reclassification in a safe and comfortable environment.

According to Calaguas [33] Teachers' job satisfaction had a significant relationship with their subjective well-being with job satisfaction significantly predicting subjective well-being.

\section{MATERIALS AND METHODS}

\section{A. Statistical Method}

This study used descriptive method to comprise the interpretation of the current situations and actual results that may apply to the respondent's population. Descriptive research "is designed to provide a picture of a situation as it naturally happens". It may be used to justify current practice and make judgment and also to develop theories Burns and Grove [34]. In this research method, researchers used survey. This research includes all Public Secondary Technology and Livelihood Education Teachers in District 1 of Marikina.

\section{B. Sampling Technique}

The researchers used COCHRAN sampling technique to determine the number of sample which is 86 out of 110 respondents. A researchers' questionnaire was administered to the selected respondents which were the Technology and Livelihood Education Teachers in District 1 of Marikina through random sampling.

\section{Instrumentation}

The data gathered should be treated to determine the aspects of job satisfaction. Since the questionnaire used by the researchers was adapted, validation and reliability testing were not utilized. [4] Items in the questionnaire are not arranged according to its aspects to avoid biases. The arrangement of the questions are as follows: Job Characteristics (1, 14, 23, 33, 28, 35, 13, 29, 17, 15, 18, 36); Social Benefits (11, 8 10, 5, 3, 6, 2, 4, 9, 24); Meaningfulness of the Job (22, 21, 31, 32); Support from Administration (24, $25,16)$ and; Intention to remain on the Job $(20,27,30)$.

\section{Data Gathering Procedure}

Data gathering for this study was through the use of survey - questionnaire. The researchers gave the questionnaires to the respondents in which they were given enough time to answer. The answered questionnaire were collected, and made sure that all items were answered. The data gathered were tallied, tabulated, analyzed and interpreted and the results became the bases for the conclusion of the study.

\section{E. Statistical Treatment of Data}

The mean was being used to identify the raw data that researchers gathered;

$$
W M \frac{\sum F X}{N}
$$

$\mathrm{t}$ - test was used to determine the significant difference between two means;

$$
t=\frac{\left(\bar{x}_{1}-\bar{x}_{2}\right)-\left(\mu_{1}-\mu_{2}\right)}{\sqrt{\frac{s_{1}^{2}}{n_{1}}+\frac{s_{1}^{2}}{n_{2}}}}
$$


ANOVA was used to determine the significant difference of more than two means;

$$
S S T=\sum_{i=1}^{r} \sum_{j=1}^{c} \sum_{k=1}^{n}\left(x_{i j k}-\bar{x}_{G M}\right)^{2}
$$

Pearsons $-r$ was used to determine the relationship of each aspect of Job Satisfaction;

$$
r=\frac{N \sum X Y-\left(\sum X\right)\left(\sum Y\right)}{\left[N\left(\sum X^{2}\right)-\left(\sum X\right)^{2}\right]\left[N\left(\sum y^{2}\right)-\left(\sum y\right)^{2}\right.}
$$

and Regression Method was used to determine what aspect why teachers intent to remain on their Job.

$$
\hat{Y}=b_{0}+b_{1} X+b_{2} X \ldots b_{n} X
$$

\section{RESULTS AND DISCUSSION}

Data gathering for this study was through the use of survey - questionnaire. The researchers gave the questionnaires to the respondents in which they were given enough time to answer. The answered questionnaire were collected, and made sure that all items were answered. The data gathered were tallied, tabulated, analyzed and interpreted and the results became the bases for the conclusion of the study.

Table 1. Frequency and Percentage in terms of Gender

\begin{tabular}{ccc}
\hline Gender & F & \% \\
\hline Male & 22 & 25.6 \\
\hline Female & 64 & 74.6 \\
\hline Overall & 86 & 100
\end{tabular}

Table 1 revealed that $25.6 \%$ of the population is male and $74.4 \%$ of the population is female. It indicates that teaching is being dominated by female.

The teaching of young children has long been dominated by women. Women's predominance in school teaching is to be found in most countries throughout the world [35]. School teaching has long been believed and thought of as a woman's profession and job because working with children was associated with child-care rather than teaching [36].

Table 2. Frequency and Percentage in terms of Age

\begin{tabular}{ccc}
\hline Age & F & \% \\
\hline $\mathbf{2 1}-\mathbf{3 0}$ & 21 & 24.4 \\
$\mathbf{3 1 - 4 0}$ & 35 & 40.7 \\
\hline $\mathbf{4 1 - 5 0}$ & 28 & 32.6 \\
\hline $\mathbf{5 1 +}$ & 2 & 2.3 \\
\hline Overall & 86 & 100
\end{tabular}

Table 2 revealed that the majority age of the teachers is between 31 - 40 years old with $40.7 \%$ and the least is $51+$ with $2.3 \%$. The result shows that most of the teacher teach in Junior High School in Marikina are in 30s and 40s. According to the OECD Teaching and Learning International Survey (TALIS), an international survey that gathers information on teachers in secondary schools, the average age of secondary school teachers in the jurisdictions included in the 2013 TALIS survey. The average teacher age ranges from 36 years in Singapore to 49 years in Italy. Teachers in England are the fifth youngest in the survey, with an average age of 39 years.
Table 3. Frequency and Percentage in terms of Marital

\begin{tabular}{ccc} 
& Status & \\
\hline Marital Status & F & \% \\
\hline Married & 63 & 73.3 \\
\hline Single & 22 & 25.6 \\
\hline Widow & 1 & 1.2 \\
\hline Overall & 86 & 100 \\
\hline
\end{tabular}

Table 3 revealed that most of the respondents are married with $73.3 \%$. It also indicates that since majority of the teachers are in 30 s and 40 s, it could possibly in this age, they are married. Odanga, Aloka, Raburu [37] concluded in 2015 that male and married teachers attempt to do more things in the school, put more effort in their work, persevere longer in their duties and recover faster when they fail to meet set targets such as school mean.

Table 4. Frequency and Percentage in terms of Teaching Experience

\begin{tabular}{ccc}
\hline $\begin{array}{c}\text { Teaching } \\
\text { Experience }\end{array}$ & F & \% \\
\hline Below 5 & 26 & 30.2 \\
\hline $\mathbf{6 ~ - 1 0}$ & 23 & 26.7 \\
\hline $\mathbf{1 1}-\mathbf{1 5}$ & 18 & 20.9 \\
\hline $\mathbf{1 6}-\mathbf{2 0}$ & 12 & 14 \\
\hline Above 21 & 7 & 8.1 \\
\hline Overall & 86 & 100 \\
\hline
\end{tabular}

Table 4 shows that the sample consisted of teachers with teaching experience ranging 6 months -35 years. $30.2 \%$ of the total respondents had a work experience of less than 5 years. Teachers gradually reach a plateau after 3-5 years on the job. As one study put it, "there is little evidence that improvement continues after the first three years." Another found that, on average, teachers with 20 years of experience are not much more effective than those with 5 years of experience.

Table 5. Frequency and Percentage in terms of type of school

\begin{tabular}{ccc}
\hline Type of School & F & \% \\
\hline High School & 25 & 29.1 \\
\hline $\begin{array}{c}\text { National High } \\
\text { School }\end{array}$ & 56 & 65.1 \\
\hline $\begin{array}{c}\text { Science High } \\
\text { School }\end{array}$ & 5 & 5.8 \\
\hline Overall & 86 & 100 \\
\hline
\end{tabular}

As shown by Table 5, the participants of the study were from three types of school and revealed that High School teachers constituted 29.1\%, National High School teachers constituted $65.1 \%$ and Science High School teachers constituted $5.8 \%$. It also reveals that science high school has the least percentage, only one science high school per city. 
PREVALENT FACTORS THAT AFFECT THE JOB SATISFACTION OF JUNIOR HIGH SCHOOL TECHNOLOGY AND LIVELIHOOD EDUCATION TEACHERS IN PUBLIC SECONDARY SCHXCOOL IN DISTRICT 1 OF MARIKINA CITY 2017 - 2018

Table 6. Frequencies and Percentage in terms of location of the school

\begin{tabular}{ccc}
\hline Location & F & \% \\
\hline Rural & 0 & 0 \\
\hline Urban & 86 & 100 \\
\hline Overall & 86 & 100
\end{tabular}
and located to NCR.

Table 7 Frequency and Percentage in terms of Grade

\begin{tabular}{ccc}
\multicolumn{3}{c}{ Level } \\
\hline Grade Level & F & \% \\
\hline $\mathbf{7}$ & 11 & 12.8 \\
\hline $\mathbf{8}$ & 20 & 23.3 \\
\hline $\mathbf{9}$ & 28 & 32.6 \\
\hline $\mathbf{1 0}$ & 27 & 31.6 \\
\hline Overall & 86 & 100
\end{tabular}

Table 7 shows that there were $32.6 \%$ Grade 9 teachers followed by Grade 10 teachers with $31.4 \%$. It reveals that it has a lot of Grade 9 and Grade 10 students in the said city.

Table 8. Frequency and Percentage in terms Leadership Positions

\begin{tabular}{ccc}
\hline Leadership & F & \% \\
\hline Leaders & 16 & 81.4 \\
\hline Not Leaders & 70 & 18.6 \\
\hline Overall & 86 & 100
\end{tabular}

Table 8 reveals that participants with leadership or promotional positions constituted $18.6 \%$ of the sample while those who did not occupy any leadership positions other than being classroom teachers constituted $81.4 \%$ as the data indicates. It indicates that majority of the teachers are merely teachers

Table 9. Frequency and Percentage in terms of Educational Qualification

\begin{tabular}{ccc}
\hline $\begin{array}{c}\text { Education } \\
\text { Qualification }\end{array}$ & $\mathbf{F}$ & $\%$ \\
\hline Induction Course & 3 & 3.5 \\
\hline $\begin{array}{c}\text { Diploma in } \\
\text { Education }\end{array}$ & 21 & 24.4 \\
\hline Bachelor's Degree & 49 & 57.0 \\
\hline Master's Degree & 13 & 15.1 \\
\hline Overall & 86 & 100
\end{tabular}

Table 9 shows that categorization of participants by their educational qualifications was as follows: $3.5 \%$ had attended induction course in education, 24.4\% had a Diploma Education, 57.0\% Bachelor's Degree and 15.1\% had a Master's Degree
Table 6 shows that since all of the schools are from Urban

Table 10. Weighted Mean and Verbal Interpretation of Job Satisfaction

\begin{tabular}{ccc}
\hline Aspects & $\begin{array}{c}\text { Weighted } \\
\text { Mean }\end{array}$ & $\begin{array}{c}\text { Verbal } \\
\text { Interpretation }\end{array}$ \\
\hline Job Characteristics & 3.48 & Neutral \\
\hline Social Benefits & 3.78 & Agree \\
\hline Meaningfulness of the Job & 3.81 & Agree \\
\hline $\begin{array}{c}\text { Support from } \\
\text { Administration }\end{array}$ & 3.54 & Agree \\
\hline $\begin{array}{c}\text { Intention to Remain on } \\
\text { the Job }\end{array}$ & 3.71 & Agree \\
\hline Overall Weighted Mean & 3.67 & Agree \\
\hline
\end{tabular}

Table 10 shows the majority of the respondents are agreed in Social Benefits with the weighted mean of 3.78; Meaningfulness of the Job with the weighted mean of 3.81 ; Support from Administration with the weighted mean of 3.54; and intention to remain on the Job with weighted mean of 3.71 as aspects on their Job Satisfaction. However, Job Characteristics got Neutral with the weighted mean of 3.48 which means teachers are not quite satisfied in this aspect. The overall weighted mean of Job Satisfaction with 3.67 reveals that teachers are satisfied in difference aspects of the Job Satisfaction.

Table 11. Significant Difference of the Job Satisfaction Aspects according to their Gender

\begin{tabular}{cccc}
\hline Gender & $\begin{array}{c}\mathbf{t}- \\
\text { Value }\end{array}$ & $\begin{array}{c}\mathbf{P}- \\
\text { Value }\end{array}$ & Remarks \\
\hline $\begin{array}{c}\text { Job } \\
\text { Characteristics }\end{array}$ & -.696 & .223 & Not Significant \\
\hline Social Benefits & -.545 & .445 & Not Significant \\
\hline $\begin{array}{c}\text { Meaningfulness } \\
\text { of the Job }\end{array}$ & -.095 & .967 & Not Significant \\
\hline $\begin{array}{c}\text { Support from } \\
\text { Administration }\end{array}$ & -1.276 & .309 & Not Significant \\
\hline $\begin{array}{c}\text { Intention to } \\
\text { Remain on the } \\
\text { Job }\end{array}$ & -.440 & .746 & Not Significant \\
\hline
\end{tabular}

Table 11 reveals that $\mathrm{P}$-value of $.223, .445, .967, .309$ and .746 respectively were no significant difference between the five aspects of job satisfaction namely; Job Characteristics; Social Benefits; Meaningfulness of the Job; Support from Administration; and Intention to Remain on the Job and Gender. It means has no effect in Job Satisfaction.

Table 12. Difference of the Job Satisfaction Aspects according to their Age and Type of School f-Value $\quad \mathbf{P}$-Value Interpretation

\begin{tabular}{cccc}
\hline Age & 1.23 & .278 & $\begin{array}{c}\text { Not } \\
\text { Significant }\end{array}$ \\
\hline $\begin{array}{c}\text { Type of } \\
\text { School }\end{array}$ & 1.30 & .256 & $\begin{array}{c}\text { Not } \\
\text { Significant }\end{array}$ \\
\hline
\end{tabular}

Table 12 shows that the $\mathrm{P}-$ Value, .278 , reveals that were no significant difference between Job Satisfaction and Age. It means age has no effect in Job Satisfaction. In the type of schools shows that the $\mathrm{P}$ - value, .256 , reveals that were no 
significant difference between Job Satisfaction and Types of School. It means types of school have no effect in Job Satisfaction.

Table 13. Significant Relationship of the Job Characteristics to four aspects

\begin{tabular}{ccccc}
\hline $\begin{array}{c}\text { Job } \\
\text { Characterist } \\
\text { ics }\end{array}$ & $\begin{array}{c}\text { Pears } \\
\text { on }-\mathbf{r}\end{array}$ & $\begin{array}{c}\text { Verbal } \\
\text { Interpretat } \\
\text { ion }\end{array}$ & $\begin{array}{c}\text { P }- \\
\text { Val } \\
\text { ue }\end{array}$ & $\begin{array}{c}\text { REMAR } \\
\text { KS }\end{array}$ \\
\hline $\begin{array}{c}\text { Meaningful } \\
\text { ness of the } \\
\text { Job }\end{array}$ & .752 & $\begin{array}{c}\text { High } \\
\text { Correlation }\end{array}$ & .000 & $\begin{array}{c}\text { Significan } \\
\mathrm{t}\end{array}$ \\
\hline $\begin{array}{c}\text { Social } \\
\text { Benefits }\end{array}$ & .843 & $\begin{array}{c}\text { High } \\
\text { Correlation }\end{array}$ & .000 & $\begin{array}{c}\text { Significan } \\
\mathrm{t}\end{array}$ \\
\hline $\begin{array}{c}\text { Support } \\
\text { from }\end{array}$ & .893 & $\begin{array}{c}\text { High } \\
\text { Correlation }\end{array}$ & .000 & $\begin{array}{c}\text { Significan } \\
\mathrm{t}\end{array}$ \\
$\begin{array}{c}\text { Administrat } \\
\text { ion }\end{array}$ & & High & .000 & $\begin{array}{c}\text { Significan } \\
\mathrm{t}\end{array}$ \\
\hline $\begin{array}{c}\text { Intention to } \\
\text { Remain on } \\
\text { the Job }\end{array}$ & .733 & Correlation & & \\
\hline
\end{tabular}

The table 13 shows that there were significant relationships in Job Characteristics to each aspects. It can be observed that the four aspects have high correlation namely: Meaningfulness of the Job with Pearson $-r$ correlation of .752; Social Benefits with Pearson - $\mathrm{r}$ correlation of .843; Support from Administration with Pearson - $r$ correlation of .893; and Intention to Remain on the Job with Pearson - r correlation of .733. It can be generalized that Job Characteristics is correlated with four Job Satisfaction Aspects.

Table 14. Significant Relationship of the

Meaningfulness of the Job to four aspects

\begin{tabular}{ccccc}
\hline $\begin{array}{c}\text { Meaningful } \\
\text { ness of the } \\
\text { Job }\end{array}$ & $\begin{array}{c}\text { Pears } \\
\text { on }-\mathbf{r}\end{array}$ & $\begin{array}{c}\text { Verbal } \\
\text { Interpretat } \\
\text { ion }\end{array}$ & $\begin{array}{c}\text { P }- \\
\text { Val } \\
\text { ue }\end{array}$ & $\begin{array}{c}\text { REMAR } \\
\text { KS }\end{array}$ \\
\hline $\begin{array}{c}\text { Job } \\
\text { Characteris } \\
\text { tics }\end{array}$ & .752 & $\begin{array}{c}\text { High } \\
\text { Correlation }\end{array}$ & $\begin{array}{c}.00 \\
0\end{array}$ & $\begin{array}{c}\text { Significa } \\
\text { nt }\end{array}$ \\
\hline $\begin{array}{c}\text { Social } \\
\text { Benefits }\end{array}$ & .857 & $\begin{array}{c}\text { High } \\
\text { Correlation }\end{array}$ & $\begin{array}{c}.00 \\
0\end{array}$ & $\begin{array}{c}\text { Significa } \\
\text { nt }\end{array}$ \\
\hline $\begin{array}{c}\text { Support } \\
\text { from }\end{array}$ & .705 & $\begin{array}{c}\text { High } \\
\text { Correlation }\end{array}$ & $\begin{array}{c}.00 \\
0\end{array}$ & $\begin{array}{c}\text { Significa } \\
\text { nt }\end{array}$ \\
$\begin{array}{c}\text { Administra } \\
\text { tion }\end{array}$ & & High & .00 & $\begin{array}{c}\text { Significa } \\
\text { nt }\end{array}$ \\
\hline $\begin{array}{c}\text { Intention to } \\
\text { Remain on } \\
\text { the Job }\end{array}$ & .832 & Correlation & 0 & \\
\hline
\end{tabular}

Table 14 displays that there were significant relationships in Meaningfulness of the Job to each aspect. It can be observed that the four aspects have high correlation namely: Job Characteristics with Pearson $-\mathrm{r}$ correlation of .752; Social Benefits with Pearson $-r$ correlation of .857; Support from Administration with Pearson $-r$ correlation of .705; and Intention to Remain on the Job with Pearson $-r$ correlation of .832. It can be generalized that Meaningfulness of the Job is correlated with four Job Satisfaction Aspects.
Table 15. Significant Relationship of the Social Benefits to four aspects

\begin{tabular}{ccccc}
\hline $\begin{array}{c}\text { Social } \\
\text { Benefits }\end{array}$ & $\begin{array}{c}\text { Pears } \\
\text { on }-\mathbf{r}\end{array}$ & $\begin{array}{c}\text { Verbal } \\
\text { Interpretat } \\
\text { ion }\end{array}$ & $\begin{array}{c}\text { P }- \\
\text { Val } \\
\text { ue }\end{array}$ & $\begin{array}{c}\text { REMAR } \\
\text { KS }\end{array}$ \\
\hline $\begin{array}{c}\text { Job } \\
\text { Characterist } \\
\text { ics }\end{array}$ & .843 & $\begin{array}{c}\text { High } \\
\text { Correlation }\end{array}$ & .000 & $\begin{array}{c}\text { Significan } \\
\mathrm{t}\end{array}$ \\
\hline $\begin{array}{c}\text { Meaningful } \\
\text { ness of the } \\
\text { Job }\end{array}$ & .857 & $\begin{array}{c}\text { High } \\
\text { Correlation }\end{array}$ & .000 & $\begin{array}{c}\text { Significan } \\
\mathrm{t}\end{array}$ \\
\hline $\begin{array}{c}\text { Support } \\
\text { from }\end{array}$ & .771 & $\begin{array}{c}\text { High } \\
\text { Correlation }\end{array}$ & .000 & $\begin{array}{c}\text { Significan } \\
\mathrm{t}\end{array}$ \\
$\begin{array}{c}\text { Administrat } \\
\text { ion }\end{array}$ & & High & .000 & $\begin{array}{c}\text { Significan } \\
\mathrm{t}\end{array}$ \\
\hline $\begin{array}{c}\text { Intention to } \\
\text { Remain on } \\
\text { the Job }\end{array}$ & .847 & Correlation & & \\
\hline
\end{tabular}

Table 15 shows that there were significant relationships in Social Benefits to four aspects. It can be observed that the four aspects have high correlation namely: Job Characteristics with Pearson $-\mathrm{r}$ correlation of .843; Meaningfulness of the Job with Pearson $-\mathrm{r}$ correlation of .857; Support from Administration with Pearson - $\mathrm{r}$ correlation of .771; and Intention to Remain on the Job with Pearson $-r$ correlation of .847 . It can be generalized that Social Benefits is correlated with four Job Satisfaction Aspects. Spector [6] defined environmental factors influencing job satisfaction as the way people are treated, the nature of job tasks, relations with other people in the work place, and rewards and accordingly, he suggested meaningfulness of the job, supportive administration, job characteristics, social benefits, and intention to remain in the job as the job environment factors.

Table 16. Significant Relationship of Support from Administration to four aspects

\begin{tabular}{ccccc}
\hline $\begin{array}{c}\text { Support } \\
\text { From } \\
\begin{array}{c}\text { Administra } \\
\text { tion }\end{array}\end{array}$ & $\begin{array}{c}\text { Pearso } \\
\mathbf{n}-\mathbf{r}\end{array}$ & $\begin{array}{c}\text { Verbal } \\
\text { Interpreta } \\
\text { tion }\end{array}$ & $\begin{array}{c}\text { P }- \\
\text { Valu } \\
\mathbf{e}\end{array}$ & $\begin{array}{c}\text { REMAR } \\
\text { KS }\end{array}$ \\
\hline $\begin{array}{c}\text { Job } \\
\text { Characteris } \\
\text { tics }\end{array}$ & .893 & $\begin{array}{c}\text { High } \\
\text { Correlation }\end{array}$ & .000 & $\begin{array}{c}\text { Significa } \\
\text { nt }\end{array}$ \\
\hline $\begin{array}{c}\text { Meaningful } \\
\text { ness of the } \\
\text { Job }\end{array}$ & .705 & $\begin{array}{c}\text { High } \\
\text { Correlation }\end{array}$ & .000 & $\begin{array}{c}\text { Significa } \\
\text { nt }\end{array}$ \\
\hline $\begin{array}{c}\text { Social } \\
\text { Benefits }\end{array}$ & .771 & $\begin{array}{c}\text { High } \\
\text { Correlation }\end{array}$ & .000 & $\begin{array}{c}\text { Significa } \\
\text { nt }\end{array}$ \\
\hline $\begin{array}{c}\text { Intention to } \\
\text { Remain on } \\
\text { the Job }\end{array}$ & .645 & $\begin{array}{c}\text { Moderate } \\
\text { Correlation }\end{array}$ & .000 & $\begin{array}{c}\text { Significa } \\
\text { nt }\end{array}$ \\
\hline
\end{tabular}

Table 16 illustrates that there were significant relationships in Support from Administration to four aspects. It can be perceived that the three aspects have high correlation namely; Job Characteristics with Pearson $-\mathrm{r}$ correlation of .893; Meaningfulness of the Job with Pearson $-r$ correlation of 


\section{PREVALENT FACTORS THAT AFFECT THE JOB SATISFACTION OF JUNIOR HIGH SCHOOL TECHNOLOGY AND LIVELIHOOD EDUCATION TEACHERS IN PUBLIC SECONDARY SCHXCOOL IN DISTRICT 1 OF MARIKINA CITY 2017 - 2018}

.705; and Social Benefits with Pearson - r correlation of .771. On the other hand, Intention to Remain on the Job has moderate correlation with Pearson $-r$ correlation of .645. It can be generalized that Support from Administration is correlated with four Job Satisfaction Aspects.

Table 17. Significant Relationship of Intention to Remain on the Job to four aspects

\begin{tabular}{ccccc}
\hline $\begin{array}{c}\text { Intention to } \\
\text { Remain on } \\
\text { the Job }\end{array}$ & $\begin{array}{c}\text { Pear } \\
\text { son } \\
-\mathbf{r}\end{array}$ & $\begin{array}{c}\text { Verbal } \\
\text { Interpreta } \\
\text { tion }\end{array}$ & $\begin{array}{c}\text { P }- \\
\text { Valu } \\
\mathbf{e}\end{array}$ & REMARKS \\
\hline $\begin{array}{c}\text { Job } \\
\text { Characteris } \\
\text { tics }\end{array}$ & .733 & $\begin{array}{c}\text { High } \\
\text { Correlation }\end{array}$ & .000 & Significant \\
\hline $\begin{array}{c}\text { Meaningful } \\
\text { ness of the } \\
\text { Job }\end{array}$ & .832 & $\begin{array}{c}\text { High } \\
\text { Correlation }\end{array}$ & .000 & Significant \\
\hline $\begin{array}{c}\text { Social } \\
\text { Benefits }\end{array}$ & .847 & $\begin{array}{c}\text { High } \\
\text { Correlation }\end{array}$ & .000 & Significant \\
\hline $\begin{array}{c}\text { Support } \\
\text { from }\end{array}$ & .645 & $\begin{array}{c}\text { Moderate } \\
\text { Correlation }\end{array}$ & .000 & Significant \\
$\begin{array}{c}\text { Administra } \\
\text { tion }\end{array}$ & & & & \\
\hline
\end{tabular}

Table 17 shows that there were significant relationships in Intention to Remain on the Job to four aspects. It can be observed that three aspects have high correlation namely; Job Characteristics with Pearson $-\mathrm{r}$ correlation of .733; Meaningfulness of the Job with Pearson $-r$ correlation of .832; Social Benefits with Pearson $-r$ correlation of .847 . On the other hand, support from Administration has moderate correlation with Pearson $-\mathrm{r}$ correlation of .645. It can be generalized that Intention to Remain on the Job is correlated with four Job Satisfaction Aspects.

The Case of Njombe District in 2009, he answered the research question "Is there any significant relationship between teacher job satisfaction and job characteristics, social benefits, meaningfulness of the job, support from administrators and intention to remain in the job?" As a result of his research, it indicated that there is a significantly relationship between job satisfaction and job characteristics, administrators and intention to remain in the job, except for social benefits and intention to remain on the job, which means that all these five dimensions have casual relationship to one another. [4]

Table 18. Predictors of Intention to Remain on the Job

\begin{tabular}{|cccc|}
\hline Job Satisfaction & F & $\begin{array}{c}\text { P- } \\
\text { Value }\end{array}$ & Remarks \\
\hline Job Characteristics & 1.000 & .320 & $\begin{array}{c}\text { Not } \\
\text { Significant }\end{array}$ \\
\hline $\begin{array}{c}\text { Meaningfulness of } \\
\text { the Job }\end{array}$ & 3.869 & .000 & Significant \\
\hline $\begin{array}{c}\text { Social Benefits } \\
\text { Support from } \\
\text { Administration }\end{array}$ & $\mathbf{3 . 7 6 2}$ & .000 & Significant \\
\hline
\end{tabular}

The table 18 shows that two aspects of Job Satisfaction have significant contribution to Teachers' Intention to Remain on the Job. It can be observed that Meaningfulness of the Job with P-Value of .000 and Social Benefits with P Value of .000 are significant in Teachers' Intention to social benefits, meaningfulness of the job, support from

Remain on the Job. Teachers think that teaching is a noblest profession to work on because this is not a merely job but it is a job which affects other people's lives [5]. In the Philippines, there a lot of benefits that could gain of teachers like recognition that is giving to them by their former students even the current. According to Fourie and Deacon [38], the main antecedents of meaning in work for teachers was strongly linked to the main task of education, including the transfer of knowledge and making a positive contribution to their future through a strong, trusting relationship. The need for feedback (both tangible and intangible in the form of appreciation and gratitude) were found to be related to the transfer of knowledge, making a positive difference, and tangible results, as all of these are indicators of how well teachers are performing. For social benefits, as Ngimbudzi cited Herzberg [4], this dimension includes recognition from community, coworkers, autonomy/freedom, responsibility, work itself and job security. The results are consistent with Herzberg's Two-Factor Theory in which recognition, responsibility and work itself are referred to as satisfiers. In terms of job security, aside from the permanent position given to secondary public-school teachers. In the Philippines, they also receive cash incentives such as mid-year and year-end bonuses in accordance to Budget Circular Number 17 and Executive Order No. 201 Sec. 4. They may also get their Performance Based Bonus as per Executive Order No. 201 Sec. 5.

\section{CONCLUSION AND RECOMMENDATION}

The study conducted was aimed to identify what are the aspects of Job Satisfaction junior high school teachers in the Division Schools-Marikina District I are satisfied to. It aimed to examine the demographic profile of the respondents. The data revealed that in terms of sex; most of the respondents were female. In terms of age; data showed that most of the respondents were in the age of 31-40. In addition, most of the respondents revealed that they were married. About the teaching experience, data showed that most of the respondents taught in less than 5 years, then, they can be considered as new in the profession. As the type of school is concern, data revealed that most of the respondents were teaching in national high schools. In terms of location of the school, all schools were located at urban. In terms of grade level, most of the respondents were teaching grade 9 students. Moreover, most of the teachers did not have leadership position in the school. Lastly, most of the respondents had bachelor's degree. It was also intended to identify the aspect of job satisfaction that teachers satisfied with. Data showed that teachers were satisfied except in job characteristics. Thus, the overall result revealed that teachers were satisfied in different aspects of job satisfaction. It aimed to determine if there is any significant difference in job satisfaction aspects and gender, age, and types of school. Thus, the results showed that there was no significant difference. It was intended to determine the significant relationship among job satisfaction aspects. It showed that job satisfaction aspects had high correlation in job satisfaction, meaningfulness of the 
job and social benefits except for support from administration and intention to remain on the job had moderate correlation. Then, all job satisfaction aspects had significant relationship. The last research question intended to determine the significant factors contribute to teachers' intention to remain on the job characteristics, meaningfulness of the job, social benefits, and support from administration. The data revealed that there were significant relationship between intention to remain on the job and meaningfulness of the job and social benefits. Thus, there were no significant relationships between intention to remain on the job and job characteristics and support from administration.

The researchers recommend in the further studies related to this research, the respondents to be included are faculty, coordinators, and principals, also, include the schools located at rural communities to have a comparison on the level of satisfaction of teachers holistically. In the area of job satisfaction aspects, administration might have a clear content and natures of the tasks teachers are assigned. They might look in to consideration the following element such as skill variety, task variety, task significance, and autonomy and job feedback. In addition; it is one of the factors why teachers do not remain on the job. Moreover, administration should pay attention on supporting teachers because this aspect contributes to teachers' intention to remain on the job. Lastly, the teachers' job satisfaction is a multidimensional phenomenon. There are other aspects, factors, and theories that can be used to fully identify the level of satisfaction of teacher.

\section{REFERENCES} Performance and Job Satisfaction among Teachers", p. 251, 2013

2. Gonzales, A. Educator's Congress Speech, 2000.

3. Crossman, A. and Harris, P. "Job satisfaction of secondary school teachers. Educational Management and Leadership", Vol. 34 No. 1, 29-46, 2006.

4. Ngimbuzi, F.W. "Job Satisfaction Among Secondary School Teachers in Tanzania: The Case of Njombe District. University of Jyvaskyla, Tanzania”, 2009.

5. Mbua, F. N. Educational Administration: Theory and Practice. Limbe, South West Province, Cameroon: Design House. (2003).

6. P. E. "Job Satisfaction: Application, Assessment, Causes, and Consequences" California: Sage Publications, 1997.

7. T. (2017). Job Satisfaction as Determinants of Organizational Performance, 289

8. Tabuso, J. A. (2007). Organizational commitment of the faculty of the Divine World College of Vigan. Retrieved from

http://www.eisrjc.com/documents/Organizational_Comm itment_Of_The_Faculty_Of_The_DWCV_132 5750682.pdf. Manuscript submitted for publication.

9. Gamboa, R. (2014, September 25). Paying tribute to the Filipino teacher. Retrieved May 18, 2018, from https://www.philstar.com/business/2014/09/25/1372753/ paying-tribute-filipino-teacher

10. Briones, L. (2016). Metrobank Foundation's Most Outstanding Teachers. Speech.

11. Bolin, F. (2007). A study of teacher job satisfaction and factors that influence it. Chinese Educational Society, 40(5):47-64.

12. Mason, S. E. (1997). Acase study of gender differences in job satisfaction subsequent to implementation of an employment equity programme. British Journal of
1. Langguyuan-Kadtong, M. and Usop, D. "Work

Management, 8, 163-173.

13. Ma, X. \& MacMillan, R. (2001). Influences of work place conditions on teachers"e job satisafaction. The Journal of Educational Research, 93, No. 1, 39-47.

14. Bishay, A. (1996). Teacher motivation and job satisfaction: a study employing the experience sampling method. Journal of Undergraduate Sciences, 3, 147-154.

15. Zhongshan, Z. (2008). Study of job satisfaction among elementary schools in Shanghai. Chinese Educational Society, Vol. 40, No. 5, 40-46.

16. Crossman, A. and Harris, P. (2006). Job satisfaction of secondary school teachers. Educational Management and Leadership, Vol. 34 No. 1, 29-46.

17. Rasku, A., \& Kinnunen, U. (2003). Job Conditions and Wellness among Finnish Upper Secondary School Teachers. Psychology and Health, 18 No. 4, 441-456.

18. Greenberg, J. and Baron, R. (1995). Behavior in Organizations. Englewood Cliffs, New Jersey: Prentice Hall.

19. Bennell, P. \& Akyeampong, K. (2007). Teacher Motivation in Sub-Saharan Africa and South Asia. DFID Department of international Development, 71.

20. Andal, E. (2015) Correlates of Job Satisfaction and Performance among the Faculty of Laguna State Polytechnic University, San Pablo City Campus: Input to Faculty Development Program, 244

21. Davidson, E. (2007). The Pivotal Role of Teacher Motivation in Tanzania. The Educational Forum, 157-166.

22. Woods, A. M. \& Weasmer (2002). Maintaining job satisfaction: Engaging professionals as active participants. The Clearing House. 75, No. 4, $186-189$.

23. Latham, A. (1998). Teacher satisfaction. Association of Supervision and Curriculum development, 82-83.

24. Langguyuan-Kadtong, M. and Usop, D. (2013). Work Performance and Job Satisfaction among Teachers, 251

25. Pilarta, M. (2015) Job Satisfaction and Teachers Performance in Abra State Institute of Sciences and Technology, 84

26. Hackman, J. R \& Oldham, G.R (1976). 'Motivation through the design of work' Organizational Behaviour and human performance, 16: 250-279.

27. Gosnell, S. (2000). Determinants of Job Satisfaction among Federal Employees. PUBP8555: Research Seminar in Public policy. A Paper Presented in Georgia Institute of Technology on the 17th April 2000.

28. Michaelowa K 2002. Teacher Career Satisfaction, Student Achievement, and the Cost of Primary Education in Francophone Sub-Saharan Africa. Hamburg Institute of International Economics.

29. Gonzales, A. (2000). Educator's Congress. Speech.

30. Getzels, J. W., \& Guba, E. G. (1968). Social behavior and the administrative process.

31. Fatima F, Ali S (2016). The Impact of Teachers' Financial Compensation on their Job Satisfaction at Higher Secondary Level. J Socialomics 5:164. doi:10.41 72/2167-0358.1000164

32. Romero, G. and Bantigue, N. (2017). JOB SATISFACTION LEVEL OF K TO 12 TEACHERS UTILIZING MULTIPLE STATISTICAL TOOLS, 8

33. Calaguas, G. (2017). Satisfied and Happy: Establishing Link between Job Satisfaction and Subjective Well- Being (Vol. 5). Asia Pacific Journal of Multidisciplinary Research.

34. Burns, N. \& Grove, S.K. 2003. Understanding nursing research. 3rd ed. Philadelphia: Saunders Company. 
35. Drudy, Sheelagh (2008) 'Gender balance/gender bias: the teaching profession and the impact of feminisation', Gender and Education, 20 (4), 309- 323

36. Skelton, C. (2009). Failing to get men into primary teaching: a feminist critique. Journal of Education Policy, (24) $1,39-54$

37. Odanga, S.J.O, Raburu, P. A., \& Aloka, P.J.O. (2015). Influence of Gender on Teachers' Self - Efficacy in Secondary Schools of Kisumu County, Kenya. Academic Journal of Interdisciplinary Studies. Vol. 4, No. 3.

38. Fourie, M., \& Deacon, E. (2015). Meaning in work of secondary school teachers: A qualitative study. South African Journal of Education, 35(3), 1-8. doi:10.15700/saje.v35n3a1047 